\title{
Response of Bread Wheat (Triticum Aestivium L.) Yield and Yield Components to Different Level of Phosphorous in Gozamen District, East Gojjam
}

\author{
Tegegnework Gebremedhin \\ College of Agriculture and Natural Resource, Department of Plant Sciences, Debre Markos University, Debre Markos, Ethiopia

\section{Email address:} \\ tegegne90@gmail.com

\section{To cite this article:} \\ Tegegnework Gebremedhin. Response of Bread Wheat (Triticum Aestivium L.) Yield and Yield Components to Different Level of \\ Phosphorous in Gozamen District, East Gojjam. Agriculture, Forestry and Fisheries. Vol. 8, No. 1, 2019, pp. 23-26. \\ doi: $10.11648 /$ j.aff.20190801.14
}

Received: February 1, 2019; Accepted: March 12, 2019; Published: March 29, 2019

\begin{abstract}
The field experiment was done during the cropping season of 2017 at Gozamin district, North western Ethiopia to see the influence of different rates phosphorous fertilizer on the yield and yield components of Bread wheat. The experiment was laid out by Randomized Complete Block Design (RCBD) design with three replications of six phosphorous rates (0, 23, 46, 69, 92 and $\left.115 \mathrm{~kg} \mathrm{ha}^{-1}\right)$. Significant differences in plant height $(\mathrm{cm})$, number of effective tillers per plant, number of kernels per spike, spike length $(\mathrm{cm})$, grain yield $\left(\mathrm{Q} \mathrm{ha}^{-1}\right)$ and biological yield $\left(\mathrm{Q} \mathrm{ha}^{-1}\right)$ were observed by the application of different rates of phosphorus fertilizers. However, only Harvesting index $\left(\mathrm{Q} \mathrm{ha}^{-1}\right)$ was not significantly affected by different rates of phosphorus fertilizers. It is concluded that phosphorus application at the rate of $115 \mathrm{~kg} \mathrm{ha}^{-1}$ is more conducive to achieve the maximum yield $\left(94.47 \mathrm{Q} \mathrm{ha}^{-1}\right)$ for the research area as compared to the other treatments.
\end{abstract}

Keywords: Bread Wheat, Phosphorous, Yield, Level

\section{Introduction}

Bread wheat (Triticum aestivum L.) is an annual crop plant belonging to the family Poaceae (grass family) and native to the Mediterranean region and southwest Asia [1]. This important cereal crop serves as a stable food for one-third of the world's population [2]. Ethiopia is the second largest producer of wheat in sub-Saharan Africa following South Africa, and about 1.6 million ha of land is cultivated annually for both bread and durum wheat production under rain fed conditions [3].

The high yield potential of modern wheat cultivars required high supplying phosphorus fertilizer [4]. phosphorus plays a vital role in the storage and transfer of energy within the cells, speeds up root development, and higher grain protein content. Phosphorus is an essential nutrient to enhances root growth, flowering, seed formation and seed maturation. Phosphorus is an essential nutrient required by the plant for normal growth in the vertisols of Ethiopia, because most of the agricultural soil in vertisols increases the unavailability of $\mathrm{P}$ than the total quantity present in the soil.
Phosphorus deficiency is a common soil problem in the area having a calcareous nature. The reaction of phosphate in the soil has an important contribution to crop growth and fertilizer use efficiency [5]. The availability of $\mathrm{P}$ to crops for uptake and utilization is a decline in alkaline and calcareous soil due to the decreases of solubility calcium phosphate minerals [6].

Phosphorus availability is controlled by several factors such as soil organic matter levels, soil $\mathrm{pH}$, and soil aluminum and iron contents, making it a challenge to estimate how much $\mathrm{P}$ will be supplied to the crop. Moreover, other factors, such as fertilizer placement, can significantly impact $P$ availability during the growing season [5]. Phosphorous availability in most soils is at a maximum in the $\mathrm{pH}$ range 6 to 7 . As soil $\mathrm{pH}$ increases above $7, \mathrm{Ca}$ and magnesium $(\mathrm{Mg})$ react with $\mathrm{P}$, and the availability again declines. Trying to lower the $\mathrm{pH}$ of calcareous soils to improve $\mathrm{P}$ availability is not practical. Phosphorous deficiency reduced the yield from 10 to $15 \%$ [7-26]. Also important are the size of the root system and the extent to which roots grow into the soil, and the efficiency with which roots take up Phosphorous [7]. 
The main objectives of this study were to determine the effect of phosphorous on wheat yield and yield component at different rates of $\mathrm{P}$.

\section{Material and methods}

\subsection{Description of the Study Area}

The research was done at Gozamin District, North-Western Ethiopia during the season of 2017/18 cropping season. The study areas located at a geographical location of $10^{\circ} 1^{\prime} 46^{\prime \prime}$ and $10^{\circ} 35^{\prime} 12^{\prime \prime} \mathrm{N}$ latitudes and $37^{\circ} 23^{\prime} 45^{\prime \prime}$ and $37^{\circ} 55^{\prime} 52^{\prime \prime} \mathrm{E}$ longitudes and the average rainfall for the area is $1380 \mathrm{~mm}$ per annum [8]. The average temperature also ranges between $14^{\circ} \mathrm{C}$ and $32^{\circ} \mathrm{C}$. for the area the rainfall is bimodal; the short rainy season (belg) in March to April followed by more substantial rainfall between June and September (kremt) [8].

\subsection{Treatments and Experimental Designs}

The treatments including $\mathrm{T}_{1}=0, \mathrm{~T}_{2}=23, \mathrm{~T}_{3}=46$ and $\mathrm{T}_{4}=$ 69, $\mathrm{T}_{5}=92, \mathrm{~T}_{6}=115 \mathrm{~kg} \mathrm{P}_{2} \mathrm{O}_{5} \mathrm{ha}^{-1}$ were applied to the soil at the time of sowing. The field experiment was laid out in Randomized Complete Block Design (RCBD) with three replications, The size of each plot was $2.4 \mathrm{~m} \mathrm{x} 1.6 \mathrm{~m}(3.84$ $\mathrm{m}^{2}$ ) and the distance between the experiment units was 0.5 meter while the distance between blocks was 1 meters. The net central unit areas of each plot net plot size of $2.2 \mathrm{~m} \mathrm{x} 1 \mathrm{~m}$ were used for data collection and measurement. The wheat variety Kekeba was sown on $1^{\text {st }}$ June during winter growing season of 2017 using a seeding rate of $140 \mathrm{~kg} \mathrm{ha}^{-1}$. Nitrogen fertilizer was applied in the form of urea $(46 \% \mathrm{~N})$ uniformly for all plots as per the area recommendation of $150 \mathrm{~kg} \mathrm{~N} \mathrm{ha}^{-1}$ for the experiment. The nitrogen fertilizer $(56.12 \mathrm{~kg} \mathrm{~N})$ was applied as band application at the time of planting and the remaining $92 \mathrm{~kg} \mathrm{~N}$ was applied as top-dressing at mid tillering stage of the crop (40 days after emergence) after first weeding was completed on each plot. The field was cultivation and management of weed was instigated manually during the cropping season to control weeds and weed-crop competition. Moreover, all the necessary field management practices were carried out as required during the experimental period. Plot wise harvesting was done at harvest maturity of the crop as the crops get matured in each plot.

\subsection{Soil Sampling and Analysis}

Soil samples were taken from 5 representative spots of the experimental field at $0-30 \mathrm{~cm}$ depth before sowing and one composite surface soil sample was made out of it for the purpose of characterization. The composite soil sample was prepared for analysis and was air- dried as well as grinded to pass through a $2 \mathrm{~mm}$ sieve. The Soil sample was analyzed to determine soil $\mathrm{pH}$, Soil texture, available $\mathrm{P}$, Organic carbon content, cation exchange capacity (CEC) and total $\mathrm{N}$ using different methods. Total nitrogen and available phosphorus were analyzed by following the procedure described [9-10]. The percent of organic matter and organic carbon were also determined by using wet oxidation method [11]. Soil texture was analyzed following Bouyoucos hydrometer method [12]. Furthermore, soil pH was measured potentiometrically in the supernatant suspension of a 1:2.5 liquid mixture using $\mathrm{pH}$ meter in water $\left(\mathrm{pH}-\mathrm{H}_{2} \mathrm{O}\right)$ [13]. While cation exchange capacity (CEC) was measured using 1M-neutral ammonium acetate [14]. Based on the soil analysis result, the $\mathrm{pH}$ and $\mathrm{CEC}$ of the experimental soil was 5 and $31.80 \mathrm{meq} / 100 \mathrm{~g}$ of soil, respectively. Whereas total nitrogen and available phosphorus were found $0.16 \%$ and $7.79 \mathrm{mg} / \mathrm{kg}$, respectively (Table 1). The total nitrogen and available phosphorous of the experimental site is determined with low content of these nutrients [15]. On the other hand, the organic carbon content was found $1.83 \%$ which is low [15] (Table 1). The texture of the experimental site was $62 \%$ clay, $20 \%$ silt and $18 \%$ sand; which is classified as clay based on texture triangle classification system and this type of soil conducive for crop production since clay soils absorb and hold more water and exchangeable nutrients or cations than silty or sandy soils.

Table 1. Physical and chemical properties for the soil of the experimental site.

\begin{tabular}{ll}
\hline Physical soil properties & Value \\
\hline Soil Texture & $\%$ \\
Sand & 18 \\
Silt & 20 \\
Clay & 62 \\
Textural class & Clay \\
B. Chemical Properties & \\
PH & 5.00 \\
Organic Carbon $(\%)$ & 1.83 \\
Total N $(\%)$ & 0.16 \\
Available P (mg/kg) & 7.79 \\
CEC (meq/100gm soil) & 31.80 \\
\hline
\end{tabular}

\section{Result and Discussion}

Wheat Growth and Yield components

Except the harvesting index of the crop all yield components were significantly affected by different rate of Phosphorus fertilizer.

\subsection{Plant Height}

From this experimental research the plant height was significantly influenced by different rates of phosphorous fertilizer. According to the treatments the highest plant height was recorded on $T_{6}(107.97 \mathrm{~cm})$ but the result was on par with $\mathrm{T}_{2}, \mathrm{~T}_{3}, \mathrm{~T}_{4}, \mathrm{~T}_{5}$, however it was significantly different from $\mathrm{T}_{1}(85.55 \mathrm{~cm})$ where it was recorded the list plant height Table 2 (Figure 1).

The result was parallel with the report that increasing the rate of phosphorous fertilizer was significantly increase the plant height, this might be due to better development of root system and nutrient absorption [16-17]. 
Table 2. The Effect of different rate of phosphorous fertilizer on Growth and yield Components of wheat.

\begin{tabular}{lllll}
\hline Treatments & Plant height $(\mathbf{c m})$ & Spike length $(\mathbf{c m})$ & Number of Effective tillers/plant & Number of kernel/spike \\
\hline T1 $(0)$ & 85.55 & 6.73 & 6.00 & 22.33 \\
T2 $(23)$ & 100.02 & 7.23 & 6.67 & 25.67 \\
T3 $(46)$ & 103.40 & 9.70 & 8.00 & 33.33 \\
T4 (69) & 100.50 & 9.45 & 9.00 & 24.67 \\
T5 (92) & 103.68 & 9.85 & 9.00 & 40.67 \\
T6 (115) & 107.97 & 9.75 & 8.33 & 48.00 \\
S.EM \pm & 3.99 & 0.36 & 0.80 & 1.17 \\
C.D. at 5\% & 12.58 & 1.14 & 2.53 & 3.69 \\
\hline
\end{tabular}

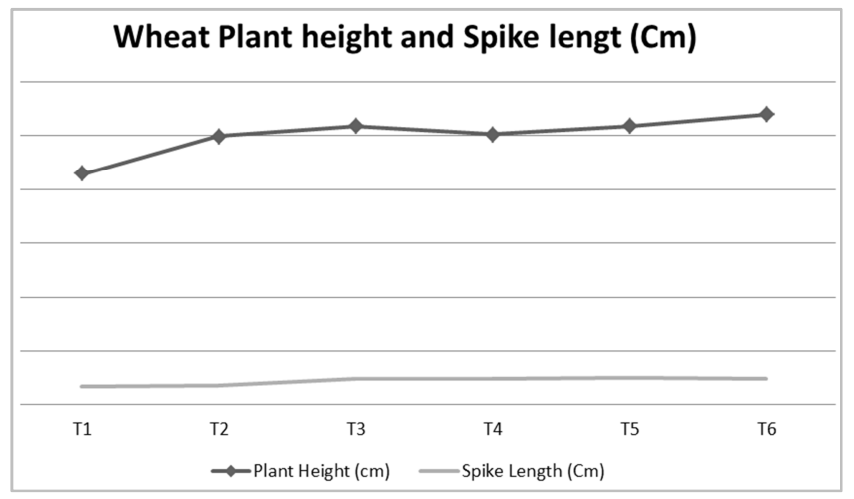

Figure 1. The Effect of different rate of phosphorus fertilizer on plant height and spike length.

\subsection{Number of Effective Tillers/Plant and Spike Length}

The effective tillers/plant and spike length of the crop were showed significantly affected by various application of phosphorous fertilizer. The analyzed data Table 2 (Figure 1) showed that the highest Number of effective tillers and Spike length was recorded on treatment $\mathrm{T}_{5}(9$ and 9.85), respectively whereas, the smallest effective tillers number and Spike length (6.00 and 6.75) respectively was recorded on $\left(\mathrm{T}_{1}\right)$. The result also identical with those proposed by [1819]. They revealed that the highest number of tillers and spike length were found under the higher phosphorous rate of application.

\subsection{Number of Kernel/Spike}

According to the analyzed data (Table 2) the highest number of spike per spike and the smallest number of kernel per spike was recorded $T_{6}(48)$ and $T_{1}(22)$, respectively but the rest of treatments were recorded a significant different as compared to the highest number of kernel per spike. The numbers of kernel per spike was increase with the highest phosphorous applied to the soil which is parallel result with [20].

\subsection{Grain Yield $\left(Q \mathrm{ha}^{-1}\right)$}

Grain yield was significantly affected by different levels of Phosphorous (Table 3). Mean values of the data showed that maximum grain yield $\left(94.47 \mathrm{Q} \mathrm{ha}^{-1}\right)$ was produced by the treatments of $\mathrm{T}_{6}$ but it was on par with $\mathrm{T}_{5}\left(84.73 \mathrm{Q} \mathrm{ha}^{-1}\right)$ the rest of treatments were recorded a significant different as compared to $\mathrm{T}_{5}$ and $\mathrm{T}_{6}$. The control plots resulted in minimum grain yield $\left(51 \mathrm{Q}^{-1} \mathrm{ha}^{-1}\right.$.
The progressive increase in grain yield of wheat recorded with increasing the level of phosphorous fertilizer [21]. The research result was supported the grain yield was increased equivalently with phosphorous fertilizer [22]. The increase in grains yields is attributed to the important role of $\mathrm{P}$ nutrient in enhancing and improving the naturally existing nutrient transformation activities in the soil profiles.

Table 3. Effect of different phosphorous rate on wheat yield, Biomass yield and Harvesting index.

\begin{tabular}{llll}
\hline Treatments & yield $\left(\mathbf{Q} \mathbf{~ h a}^{-1}\right)$ & Biological $(\mathbf{Q} / \mathbf{h a})$ & HI (\%) \\
\hline T1 $(0)$ & 51.00 & 104.00 & 49.03 \\
T2 $(23)$ & 67.67 & 145.83 & 46.40 \\
T3 (46) & 74.33 & 182.50 & 40.72 \\
T4 (69) & 75.00 & 172.67 & 43.43 \\
T5 $(92)$ & 84.73 & 181.93 & 46.57 \\
T6 $(115)$ & 94.47 & 210.80 & 44.81 \\
S.EM \pm & 5.32 & 15.25 & 0.02 \\
C.D. at 5\% & 16.78 & 48.05 & NS \\
\hline
\end{tabular}

\subsection{Biological Yield $\left(\mathrm{Q} \mathrm{ha}^{-1}\right)$}

The statistical analysis result revealed that biological yield was showed a significant different among the different rates of phosphorous fertilizer treatments (Table 3). The maximum biological yield $\left(210.80 \mathrm{Q} \mathrm{ha}^{-1}\right)$ on those plots which received the highest phosphorous fertilizer rates $\left(\mathrm{T}_{6}\right)$ but the result was statistically on par with $\left(\mathrm{T}_{5}, \mathrm{~T}_{4}\right.$ and $\left.\mathrm{T}_{3}\right)$. The lowest biological yield (104 $\left.\mathrm{Q} \mathrm{ha}^{-1}\right)$ was recorded on those plot which was not received any Phosphorous fertilizer $\left(T_{1}\right)$.

The biological yield of wheat was significantly affected by different phosphorus sources and increased with increasing phosphorus levels [23-24].

\subsection{Harvesting Index (\%)}

The statistical analysis of harvesting index was not significantly affected by different phosphorous fertilizer level, however the maximum harvesting index $(49.03 \%)$ was recorded on $\mathrm{T}_{1}$ but it was on par with all treatments. The result implies, the physiological efficiency of different crops for converting the total dry matter into final grain yield was not improved by increasing the level of phosphorous. The inline result was revealed that, phosphorus level did not significantly affect the harvest index value of maize [25]. These results also cope with the findings of the difference between varieties and their interaction with phosphorus levels was found non-significant [22]. 


\section{Conclusion}

From the present study it is possible to conclude that different phosphorous fertilizer level was affect the yield and yield components of bread wheat. The results of the data indicated that there were significant different in all agronomic traits except Harvesting index in response to the different level of phosphorous fertilizer. The application of $115 \mathrm{~kg} \mathrm{P}_{2} \mathrm{O}_{5} \mathrm{ha}^{-1}$ was increase the grain and Biological yield of wheat as compared to the other treatments 94.47 and 210 . $80 \mathrm{Q} \mathrm{ha}^{-1}$, respectively. There is a need for further experimental research in different parts of East Gojjam zone districts to determine the optimum phosphorous fertilizer requirement of the area.

\section{References}

[1] Gibson, L., \& Benson, G. (2002). Origin, History, and Uses of Oat (Avena sativa) and Wheat (Triticum aestivum). Iowa State University, Department of Agronomy. pp 3p.

[2] Hussain, M., \& Shah, S. (2002). Growth, yield and quality response of three wheat (Triticum aestivum L.) varieties to different levels of $\mathrm{N}, \mathrm{P}$ and $\mathrm{K}$. International Journal of Agriculture and Biology, 4(3), 362-364.

[3] Central Statistical Agency (2017). Agricultural sample survey. 20016/2017 Volume I Report on land utilization. Statistical Bulletin No. 302. July 2004 Addis Ababa.

[4] Clark R. (1990). Physiology of cereals for mineral nutrient uptake, use and efficiency. In: Crops as enhancers of nutrient use. (Eds.): V. C. Baligar and R. R. Dunean. Academic Press Inc., pp. 131-183.

[5] Sushanta, S., Bholanath, S., Sidhu, M., Sajal, P., \& Partha, D. (2014). Grain yield and phosphorus uptake by wheat as influenced by long-term phosphorus fertilization. African Journal of Agricultural Research, 9(6), 607-612.

[6] Alharbi, S., Ghoneim, A., Modaihsh, A., \& Mahjoub, M. (2013). Effect of Foliar and Soil Application of Phosphorus on Phosphorus Uptake, Use Efficiency and Wheat Grain Yield in Calcareous Soil. Journal of Applied Sciences, 13(1), 188-192.

[7] Syers, J., Johnston, A., \& Curtin, D. (2008). Efficiency of Soil and Fertilizer Phosphorus Use. Reconciling changing concepts of soil phosphorus behavior with agronomic information. FAO. Fertilizer and Plant Nutrition Bulletin, 18, 5.

[8] GWAO (Gozamen Woreda Agriculture Office (2014). Annual report of 2014 cropping season. Agricultural and Rural Development Office of Gozamin district of East Gojjam zone, Amhara region, Ethiopia. Unpublished.

[9] Chapman, H. (1965). Cation exchange capacity by ammonium saturation. Chemical soil analysis. pp891-901.

[10] Olsen, J., Kristensen L., Weiner, J., \& Griepentrog, W. (2005). Increased density and spatial uniformity increase weed suppression by spring wheat (Triticum aestivum L.). Weed Research, 45, 316-321.

[11] Walkely, A., \& Black, I. (1934). An examination of the degtijar method for determining soil organic matter and proposed modification of the chromic acid titration method. Soil Sci. 37, 29-38.

[12] Day, P. (1965). Hydrometer method of particle size analysis. In: Back, C. A. (eds.), Methods of soil analysis. American Society of Agronomy Journal, 9 (2), 562-563.

[13] Houba, V., VanderLee, I., Novozamsky \& Waligna I. (1989). Soil and plant analysis a sire of Syllabi, Part 5-soil Analysis procedures. Wageningen Agricultural University. The Netherlands.

[14] Jackson, M. (1967). Soil chemical analysis. Practice Hall of India. New Delhi.

[15] London, J. (1991). Booker tropical soil manual: A Handbook for Soil Survey and agricultural land evaluation in the tropics and sub tropics. Longman scientific and technical publishing, New York.

[16] Ghafoor, A. (2016). Effect of Phosphorus Fertilizer Application on Some Yield Components of Wheat and Phosphorus Use Efficiency in Calcareous Soil. Journal of Dynamics in Agricultural Research, 3(4), 46-52.

[17] Hussain, N., Khan, H., Akbar \& Akhtar, S. (2004). Growth factors and yield of maize as influenced by phosphorus and potash fertilization. Sarhad J. Agric. 22(4), 579-583.

[18] Shahzado, N., Shahmir, A., Amjad, A., Amanullah, M., Sajjad, R., Muneer, A., Syed, F., \& Sana, U. (2015). Effect of Different Levels of Phosphorus and Method of Application on the Growth and Yield of Wheat. Natural Science, 8 (1), 305314.

[19] Rahmatullah, K., Ali, R., Akber, H., Gurmani, \& Sharif, M. (2007). Effect of phosphorus application on wheat and rice yield under wheat- rice system. Sarhad J. Agric., 23 (4), 851856.

[20] Shuaib, K., Suhammad, A., Muhammad, A., Ahmad, S., Ghulam, A., \& Muhammad, R. (2009). Effect of phosphorus on the yield and yield components of wheat variety "inqlab91" under rainfed conditions. Sarhad J. Agric., 25(1), 21-24.

[21] Hussain, N., Khan M., \& Ahmad, R. (2008). Influence of phosphorus application and sowing time on performance of wheat in calcareous soils. Int. J. Agric. Biol., 10, 399-404.

[22] Remaila, S., \& Enin, M. (2017). Effect of Some Phosphorus Fertilizer Packages on Growth and Yield of Some Egyptian Wheat Varieties. Adv Crop Sci Tech., 5(2), 1-7.

[23] Khan, M., Lone, R., Ullah, S., Kaleem, \& Ahmed, M. (2010). Effect of different phosphatic fertilizers on growth attributes of wheat (Trticum aestivum L.). J. Amer. Sci., 6, 1256-1262.

[24] Saqib, B., Shazma, A., Bashir, A., Qamar, S., Wajid. K., \& Muhamad, I. (2015). Response of Wheat Crop to Phosphorus Levels and Application Methods. J. Env. and Earth Sci. 5(9), 151-155.

[25] Rana, M., \& Hafiz, Q. (2003). Effect of Phosphorus Levels on Yield Components, Grain Yield and Harvest Index of Two Maize Varieties. Asian J Plant Sci., 2(10), 800-803.

[26] Shenoy, V. V. and Kalagudi G. M. 2005. Enhancing plant phosphorus use efficiency for sustainable cropping. Biotech. Adv., 23: 501-513. 